\title{
ELECTRON SPIN RESONANCEON HYBRID NANOCOMPOSITES BASED ON NATURAL RUBBER
}

\author{
Aleksandra Ivanoska-Dacikj ${ }^{1 *}$, Gordana Bogoeva-Gaceva ${ }^{1,2}$, Srećko Valić ${ }^{3,4}$ \\ ${ }^{1}$ Research Center for Environment and Materials, Macedonian Academy of Sciences and Arts, \\ Skopje, Republic of Macedonia \\ ${ }^{2}$ Faculty of Technology and Metallurgy, Ss. Cyril and Methodius University, \\ 1000 Skopje, Republic of Macedonia \\ ${ }^{3}$ Department of Chemistry and Biochemistry, School of Medicine and Centre for Micro \\ and Nano Science and Technologies, University of Rijeka, Rijeka, Croatia \\ ${ }^{4}$ Rudjer Bošković Institute, Zagreb, Croatia \\ e-mail: aivanoska@manu.edu.mk
}

\begin{abstract}
Electron spin resonance (ESR) was used as a new method to analyze the synergy between two nanofillers different by nature, form and rigidity dispersed in natural rubber matrix. Natural rubber (NR) nanocomposites loaded with fixed amount of carbon nanotubes ( 2 parts per hundred of rubber parts; phr) and various amounts of expanded organically modified montmorillonite (EOMt, 4-20 phr) were investigated. The dependence of the double integral of the resonance spectra on the amount of EOMt present in the natural rubber was established. Its decrease with an increaseof the amount of EOMt confirmed the synergy between these two nanofillers. Also DMA temperature sweep measurements were performed and the cluster-cluster aggregation (CCA) model was used to assess the apparent filler networking energy. The obtained results suggest that the presence of the EOMt above a critical amount strengthens the hybrid-filler networking.
\end{abstract}

Keywords: electron spin resonance; carbon nanotubes; organo-montmorillonite; rubber nanocomposites

\section{INTRODUCTION}

The electron spin resonance (ESR) spectroscopy is a powerful technique for the investigation of carbon-based materials. The appearance of the carbon nanotubes ESR spectra is affected by a lot of factors and that is why different information on the carbon nanotubes ESR line shape could be found in literature. Some authors reported $[1,2]$ symmetric line shapes (mostly Lorentzian) while others reported asymmetric Dysonian line shapes [3]. The resonance spectrum of isolated carbon nanotubes should represent a symmetrical Lorentzian or Gaussian shape. On the other hand, agglomerated nanotubes are characterized by interconnected conducting domains of the order of 1 to
100 microns $[4,5]$ and such structures are characterized by resonance spectra presenting a Dysonian like shape.

Although many ESR investigations on carbon nanotubes have been reported [3, 6-14], only a few ESR studies on carbon nanotubes dispersed in polymeric matrices have been published $[8,11,13$, 14]. In these studies, based on the appearance of the ESR spectra on individual and agglomerated carbon nanotubes, it was concluded that, if the dispersion of the nanotubes is good, the resonance line will present a symmetrical shape, and if the nanotubes are aggregated and there is not a good dispersion in the polymer matrix a Dysonian-like resonance shape will appear [8]. 
In our recent publication [13] we investigated NR based hybrid nanocomposites that contained $6 \mathrm{phr}$ multiwalled carbon nanotubes (MWCNT) and various quantities of EOMt. The obtained ESR spectra had a symmetrical Lorentzian shape for all nanocomposites, indicating good dispersion of the MWCNT throughout the NR matrix, regardless of the EOMt presence and quantity. We found a sharp decrease in the double integral of the resonance spectra when EOMt quantities higher than $12 \mathrm{phr}$ were added in the matrix. The double integral of the resonance spectrum in ESR spectroscopy is proportional to the spin concentration [15]. This suggested that, above a certain amount of EOMt in the matrix, a synergism engenders between EOMt and MWCNT, resulting in a sharp spin concentration decrease in the samples. The synergism between these two nanofillers was also reported in some previous works [16-19], manifested by their better dispersion in some solvents and polymer matrices, but this was for the first time demonstrated by changes in the ESR spectra of the MWCNT in dependence of the EOMt concentration in the nanocomposites.

Motivated by this fact, we wanted to confirm that this kind of changes in the ESR spectra of MWCNT, initiated by the presence of EOMt, are repetitive and could also be observed for different concentrations of MWCNT in the NR matrix. With this in mind, we performed the ESR investigations on NR samples that contain much lower concentration ( 2 phr) of carbon nanotubes and the same concentrations of EOMt as in our previous work (4-20 phr). The appearance of the carbon nanotubes ESR spectra was analyzed and the dependence of the double integral of the resonance spectra on the amount of EOMt in the NR matrix was established. The cluster-cluster aggregation (CCA)-model [20], which is one of the fundamental micro-mechanical concepts of non-linear viscoelasticity of filled rubber, based on fractal approaches of filler networking, was used to assess the filler networking energy, which could be considered as additional indicator of fillers synergy.

\section{EXPERIMENTAL}

\section{Materials}

The NR-compounds were based on a Standard Malaysian Rubber (SMR 10). The organomontmorillonite (OMt) used was Nanofil 15 supplied from Süd-Chemie AG Moosburg, Germany. Distearyl dimethylammonium chloride (QUAT) was used as an organic modifier. The specific gravi- ty of this OMt was $1.8 \mathrm{gcm}^{-3}$ with an average particle size of $25 \mu \mathrm{m}$. Carbon nanotubes, NC7000, a multiwall carbon nanotubes (MWCNT) produced by catalytic carbon vapor deposition (CCVD) process, were supplied by NANOCYL S. A. (Belgium). They were $90 \%$ pure containing $10 \%$ metal oxides and had an average diameter of $9.5 \mathrm{~nm}$ and an average length of $1.5 \mu \mathrm{m}$. The stearic acid was purchased from ACROS Organics, Geel, Belgium with $97 \%$ purity. The vulcanizing accelerators Ntert-Butyl-2-benzothiazolesulfenamide (TBBS) and $\mathrm{N}$-cyclohexyl-2-benzothiazolesulfenamide (CBS) were provided from Rhein Chemie Rheinau $\mathrm{GmbH}$, Mannheim, Germany. Sulfur (S), N-(1,3-Dimethylbutyl)-N'-phenyl-p-phenylenediamine (6PPD) and zinc oxide $(\mathrm{ZnO})$ used in this study were of industrial grade.

\section{Preparation of the rubber nanocomposites}

The commercial OMt was first expanded by intercalation of stearic acid in the interlayer space prior to its incorporation in the rubber matrix [21]. This preparation is described in detail in reference [18]. The preparation of the hybrid rubber nanocomposites containing expanded $\mathrm{OMt}$ and MWCNT was performed in two steps, in an internal mixer (Haake Rheomix) and in an open two roll mill (Polymix 110 L, size: $203 \times 102 \mathrm{~mm}$ Servitec $\mathrm{GmbH}$, Wustermark, Germany). The formulations of NR compounds expressed as parts per hundred of rubber (phr) are shown in Table 1. The procedure is fully described in reference [18].

Table 1. Formulation of different NR compounds

\begin{tabular}{lccc}
\hline Sample code & NR $^{*}$ & MWCNT & EOMt \\
\hline NR/h200 & 100 & 2 & 0 \\
NR/h222 & 100 & 2 & 4 \\
NR/h244 & 100 & 2 & 8 \\
NR/h266 & 100 & 2 & 12 \\
NR/h288 & 100 & 2 & 16 \\
NR/h21010 & 100 & 2 & 20 \\
\hline
\end{tabular}

* Mass of the ingredients was taken in parts per hundred of rubber (phr). The ingredients which amounts were kept constant in all compounds were $\mathrm{ZnO} 5 \mathrm{phr}$, stearic acid 2 phr, 6PPD 1 phr, CBS 1.5 phr, TBBS $0.2 \mathrm{phr}$ and S $1.5 \mathrm{phr}$.

The test samples were molded and cured to 2 $\mathrm{mm}$ plates by compression molding $(150 \mathrm{kN})$ on an electrically heated hydraulic press at $150{ }^{\circ} \mathrm{C}$. The rubber samples were vulcanized up to their respective optimum cure time $\left(t_{90}\right)$, previously determined with a vulcameter (Scarabaeus, Langgöns, Germa- 
ny), and then stored for 24 hours before the tests were performed.

\section{Characterization}

Electron spin resonance (ESR) measurements were performed on a Varian E-109 spectrometer operating at $9.29 \mathrm{GHz}$, equipped with a Bruker ER 041 XG microwave bridge and a Bruker ER 4111 VT temperature unit. Spectroscopic parameters were: microwave power $10.0 \mathrm{~mW}$, modulation amplitude $0.1 \mathrm{mT}$, scan range $10 \mathrm{mT}$ and scan time $60 \mathrm{~s}$. The measurements were performed at room temperature.

Dynamic mechanical analysis was performed using a dynamic mechanical thermal spectrometer (Gabo Qualimeter, Ahlden, Germany, model Eplexor 2000N) in the tension mode. Temperature sweep analysis was carried out using a constant frequency of $10 \mathrm{~Hz}$ in a temperature range from $80{ }^{\circ} \mathrm{C}$ to $+80^{\circ} \mathrm{C}$. For the measurement of the complex modulus $\left(E^{*}\right)$, a static tensile load of $1 \%$ prestrain was applied and then the samples were oscillated with a dynamic strain of $0.5 \%$. The measurements were performed with a heating rate of 2 $\mathrm{Kmin}^{-1}$ under liquid nitrogen flow.

\section{RESULTS AND DISCUSSION}

The ESR spectrum of 2 phr MWCNT incorporated in the NR based nanocomposite, NR/h200, at room temperature is presented in Figure 1.

A narrow, symmetrical and intense line is observed, reminiscent of the ESR spectrum of pristine CNT [22].

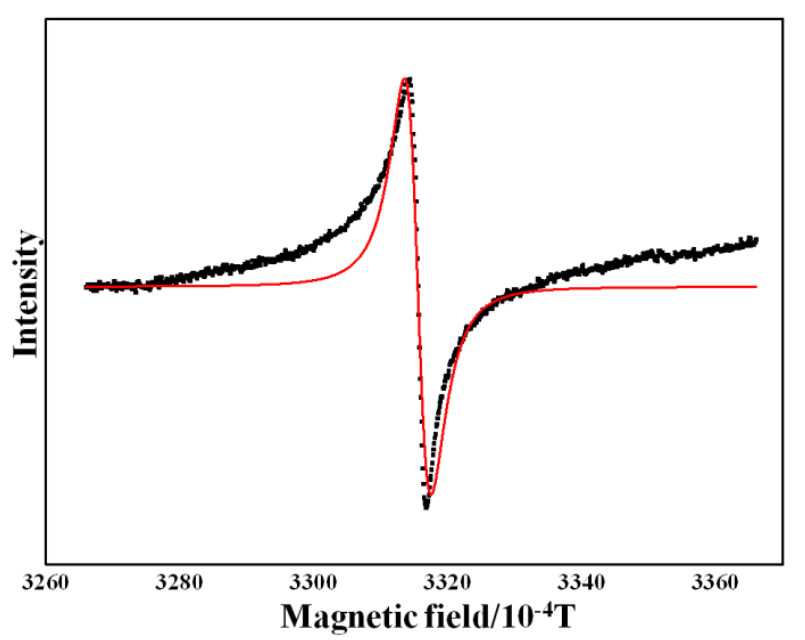

Figure 1. The ESR spectrum of 2 phr MWCNT incorporated in NR based nanocomposite (NR/h200), at room temperature
For a random distribution of CNT the resonance spectrum presents a symmetrical Lorentzian or Gaussian shape. The obtained spectrum was fitted by a Lorentzian line shape [23]:

$$
I=16 I_{0} \frac{\left(\frac{H-H_{R}}{H_{P P} / 2}\right)}{\left(3+\left(\frac{H-H_{R}}{H_{P P} / 2}\right)^{2}\right)^{2}}
$$

where $I_{0}$ is the intensity of the resonance line, $H_{P P}$ is the resonance line width and $H_{R}$ is the resonance field.

The solid line in Figure 1 represents the best fit obtained by using Equation (1). The agreement between the recorded spectrum and the theoretical shape in the peak region is good. In composite materials, if nanotubes are well dispersed throughout the matrix below the electrical percolation threshold, the resonance line will also have a symmetrical Lorentzian shape [8]. Here, the good agreement between the theoretical Lorentzian shape and the recorded resonance spectrum proves the good dispersion of the nanotubes within the NR matrix. This finding coincides with the finding in our previous investigation [18], in which transmission electron microscopy (TEM) was used as a method to estimate the dispersion of the nanofiller system in these samples. This again confirms that the predispersion of MWCNT in ethanol and the high viscosity of the rubber, which causes occurrence of strong shearing forces during the process of mixing, are sufficient to induce the separation of the individual CNT from their aggregates and to successfully form nanocomposites [18, 21].

To investigate, in this case (a lower quantity of MWCNT in the nanocomposites), the influence of the EOMt content on the resonance line position ( $g$-factor) and the double integral, ESR measurements were performed on all samples. The ESR spectra of NR-nanocomposites containing $2 \mathrm{phr}$ MWCNT but different quantities of EOMt $(0,4,8$, $12,16,20 \mathrm{phr}$ ), normalized to the sample weight, are shown in Figure 2.

All lines have the same Lorentzian shape, which proves that the good dispersion of the nanotubes within the NR matrix is not disrupted by the presence of EOMt, regardless of its quantity within investigated concentration range. 


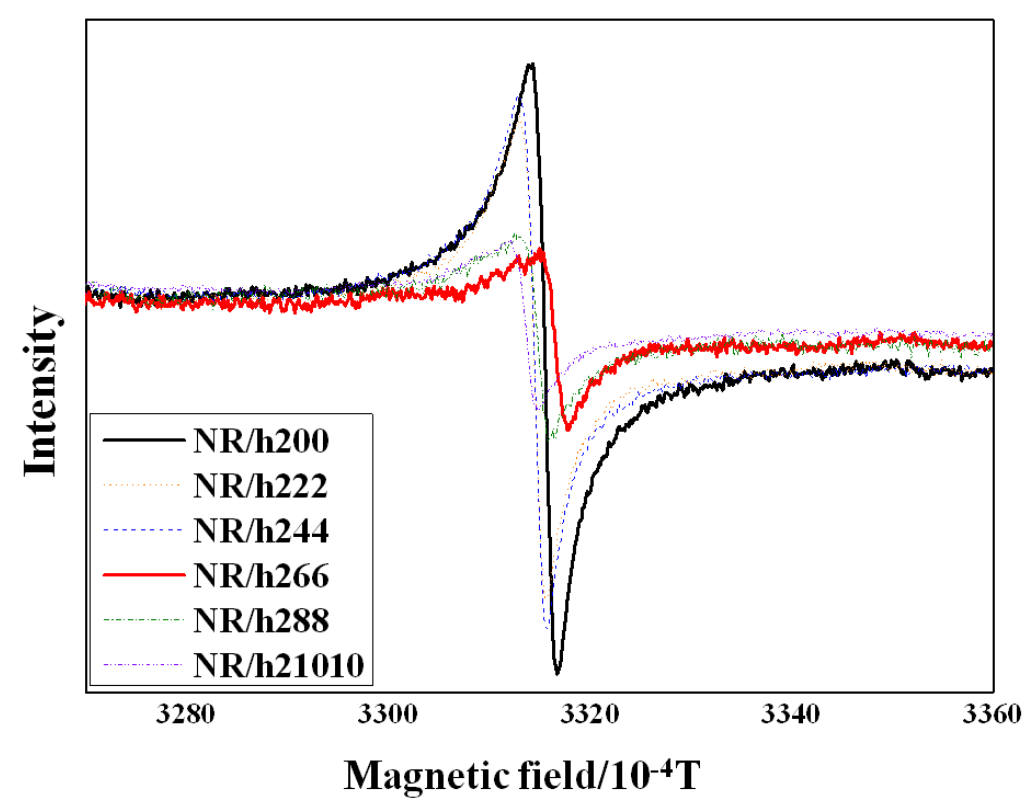

Figure 2. ESR spectra, normalized to the sample weight, of NR-nanocomposites with 2 phr MWCNT and different contents of EOMt, measured at room temperature

Chiparaet al. [8] found the position of the resonance line of carbon nanotubes dispersed in epoxy resin to be located near the free electron $g$ factor value. Their investigations showed the temperature independence of the $g$-factor, which led them to the conclusion that the resonance spectrum of CNT in epoxy resin composites originates from the uncoupled electronic spins delocalized over the carbon nanotubes. $g$-factor is:

For an uncoupled electronic spin $(s=1 / 2)$ the

$$
g=\frac{h v}{\beta H_{R}}
$$

where $h$ is the Planck's constant, $\beta$ is the Bohr magneton of the electron, $v$ is the frequency of the microwave field and $H_{R}$ is the value of the external magnetic field at which the resonance is observed.

Assuming that the resonance spectra of the MWCNT incorporated in the NR-based nanocomposites originate from the uncoupled electronic spins delocalized over the CNT, we calculated the $g$-factor according to Equation (2). These values are presented in Table 2 along with the values of the double integral obtained from the data presented in Figure 2.

The $g$-factor values (Table 2) for all samples are close to the free electron $g$-factor value $\left(g_{0}=\right.$ $2.0023)[24,25]$ and are only slightly changing with the presence of EOMt and its quantity.
Table 2. Double integral of the resonance spectra, normalized to weight, and $g$-factor values for all NR nanocomposites

\begin{tabular}{lcc}
\hline Sample code & g-factor & $\begin{array}{c}\text { Double integral / m } \\
(\mathrm{mg})\end{array}$ \\
\hline $\mathrm{NR} / \mathrm{h} 200$ & 2.0029 & 1507 \\
$\mathrm{NR} / \mathrm{h} 222$ & 2.0035 & 1211 \\
$\mathrm{NR} / \mathrm{h} 244$ & 2.0036 & 1416 \\
$\mathrm{NR} / \mathrm{h} 266$ & 2.0023 & 630 \\
$\mathrm{NR} / \mathrm{h} 288$ & 2.0036 & 581 \\
$\mathrm{NR} / \mathrm{h} 21010$ & 2.0040 & 544 \\
\hline
\end{tabular}

On the other hand, the established dependence of the double integral of resonance spectra on the amount of EOMt showed a sharp decrease when EOMt quantities higher than $8 \mathrm{phr}$ are introduced into the matrix. Intrinsically this is the same amount of EOMt as found in our previous study, but in this case the decrease is even more pronounced. Solid lines in Figure 2 indicate the resonance spectra of the sample containing only MWCNT (NR/h200) and that with additional 12 phr EOMt (NR/h266) where the sharp decrease in the double integral of the resonance spectra occurs. Since the double integral of the resonance spectrum in ESR spectroscopy is proportional to the spin concentration [15], this suggests that above a certain concentration of EOMt a synergism engenders between EOMt and MWCNT, resulting in a sharp spin concentration decrease in the samples. 
It is interesting to see how this synergism influences the filler networking, which is determined by the morphological arrangement of the filler particles and formation of joints by filler-filler bonds. Hence, to assess the filler-networking energy of the hybrid nanofillers for different MWCNT/EOMtratios, the cluster-cluster aggregation (CCA) model was used. This model is based on the assumption of geometrical arrangements of sub-units resulting from the kinetical cluster-cluster aggregation [26]. According to this model the temperature or frequency dependence of the elastic modulus of the CCA clusters is governed by the immobilized, glassy polymer between adjacent filler particles and is determined by that of a glassy polymer. In the high temperature range, well above the bulk glass transition temperature of the polymer system, an Arrhenius temperature behavior for the elastic modulus is expected, which is typically found in polymers in the glassy state. This Arrhenius like behavior, in a somewhat different interpretation, could be understood by referring it to the transition of the glassy polymer bridges between adjacent filler particles of the filler network, i.e., the apparent filler networking energy. In Figure 3 the relationships between the natural logarithm of storage modulus, $\ln \left(E^{\prime}\right)$ of the different NR based composites and the inverse temperature, far above the glass-rubber transition region $\left(10^{3} T \sim 3.4\right.$ to $2.8 \mathrm{~K}^{-1}$; corresponding $T \sim 20{ }^{\circ} \mathrm{C}$ to $80{ }^{\circ} \mathrm{C}$ ), are presented. These results are obtained from the DMA temperature sweep measurements. If the Krause assumption [27] that the dynamic modulus is proportional to the number of sub unites (e.g., filler aggregates) is used, then the straight lines obtained have a slope $E_{c} / R$, where $E_{c}$ is the activation energy or, in our case, filler networking energy, and $R$ is the gas constant.

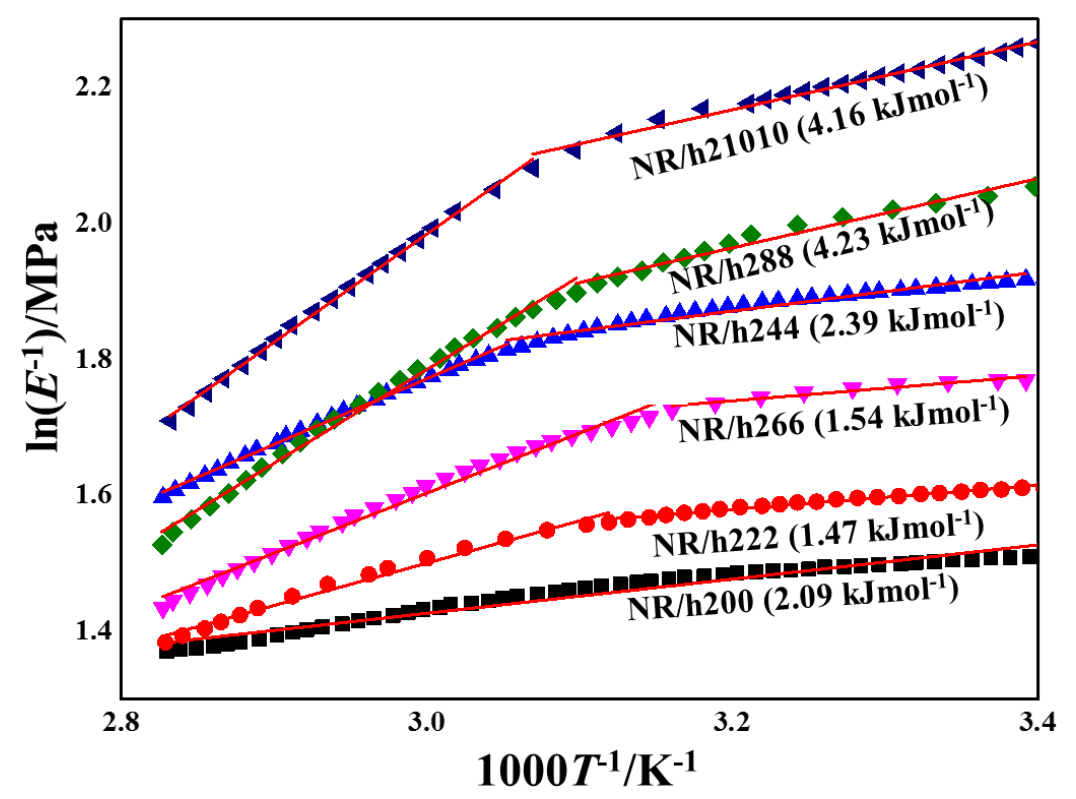

Figure 3. Natural logarithm of storage modulus as a function of reciprocal absolute temperature for the different NR nanocomposites

For the NR/h200 nanocomposite containing only MWCNT there is only one linear relationship between $\ln (E)$ and the inverse temperature. For the composites containing the hybrid nanofiller there are two distinct mechanisms with different activation energies. Similar behavior of NR nanocomposites was found in our previous study [13]. Based on the obtained results, we can conclude that the linear relationship that occurs below $\sim 60{ }^{\circ} \mathrm{C}$ (but still well above the bulk glass transition temperature of the polymer system) corresponds to the apparent filler networking energies and the other, oc- curring above $\sim 60{ }^{\circ} \mathrm{C}$, is connected to melting of the stearic acid, used to expand the galleries of OMt layers. The filler networking energies for the different ratios of MWCNT and EOMt are calculated from the slopes and are presented in Figure 3.

The filler networking energy for the nanocomposite containing only MWCNT is $2.09 \mathrm{~kJ} / \mathrm{mol}$. The addition of EOMt first causes a reduction of the filler networking energy and then it starts to increase with increase of EOMt content, reaching the maximum value of $4.23 \mathrm{~kJ} / \mathrm{mol}$ for $16 \mathrm{phr}$ of EOMt and then followed by a slight decrease for 20 
phr. This decrease is due to the re-agglomeration of the EOMt which was already concluded by XRD and TEM investigations. The obtained results clearly show that the presence of the EOMt above some critical concentration can strengthen the hybridfiller networking in NR nanocomposites.

\section{CONCLUSION}

The method of ESR can be successfully applied for analysis of the interactions between the MWCNTs and EOMt in NR hybrid filler nanocomposites. Electron spin resonance (ESR) spectra of multi-walled carbon nanotubes (MWCNT) in natural rubber (NR) based nanocomposites filled with MWCNT/EOMt hybrid filler have a symmetrical Lorentzian shape, indicating good dispersion of the MWCNT throughout the NR matrix, regardless of the EOMt concentration. The sharp decrease in the double integral of the resonance spectra, when EOMt quantities higher than $8 \mathrm{phr}$ are used in the matrix, suggested that above a certain amount of EOMt a synergism engenders between the two nanofillers, resulting in a sharp spin concentration decrease. This was for the first time demonstrated by changes in the ESR spectra. Whit these findings it is shown that the synergism between these two nanofillers, which led to their better dispersion in some solvents and polymer matrices, is also manifested by changes in the ESR spectra on the MWCNT in dependence of the concentration of EOMt in nanocomposites. The apparent filler networking energy, assessed by applying the CCAmodel to the results from the DMA temperature sweep measurements, suggested that the presence of EOMt strengthens the hybrid-filler networking when its concentration reaches critical value.

Acknowledgement: The authors gratefully acknowledge the COST action CM1302 (SIPs) for financing the Short Term Scientific Mission in Rudjer Bošković Institute in Zagreb during which the ESR measurements were performed. We also thank Prof. Gert Heinrich from the Leibniz Institut for polymer research in Dresden for the realization of the research stay in this Institute during which the samples were prepared. This work was partially supported by the Croatian Science Foundation project 1102 and RISK project from the University of Rijeka.

\section{REFERENCES}

[1] S. Bandow, Magnetic properties of nested carbon nanostructures studied by electron spin resonance and magnetic susceptibility measurements, J. Appl. Phys., 80 (1996), pp. 1020-1027.

DOI: http://dx.doi.org/10.1063/1.362835
[2] J. N. Coleman, D. F. O'Brien, A. B. Dalton, B. McCarthy, B. Lahr, R. C. Barklie, W. J. Blau, Electron paramagnetic resonance as a quantitative tool for the study of multiwalled carbon nanotubes, J. Chem. Phys., 113 (2000), pp. 9788-9793. DOI: http://dx.doi.org/10.1063/1.1322032

[3] P. Petit, E. Jouguelet, J. E. Fischer, A. G. Rinzler, E. E. Smalley, Electron spin resonance and microwave resistivity of single-wall carbon nanotubes, Phys. Rev. B., 56 (1997), pp. 9275-9278. DOI: http://dx.doi.org/10.1103/PhysRevB.56.9275

[4] L. C. Venema, V. Meunier, Ph. Lambin, C. Dekker, Atomic structure of carbon nanotubes from scanning tunneling microscopy, Phys. Rev. B, 61 (2000), pp. 2991-2996.

DOI: http://dx.doi.org/10.1103/PhysRevB.61.2991

[5] T. Belin, F. Epron, Characterization methods of carbon nanotubes: a review, Mat. Sci. Eng. BSolid., 119 (2005), pp, 105-118.

DOI: http://dx.doi.org/10.1016/j.mseb.2005.02.046

[6] K. Shen, D. L. Thierney, T. Pietrass, Electron spin resonance of carbon nanotubes under hydrogen adsorption, Phys. Rev. B, 68 (2003), pp. 165418.

[7] H. Yokomichi H, Changes in electron spin resonance spectra of carbon nanotubes by thermal annealing, Vacuum, 3-4 (2004), pp. 677-681.

[8] M. Chipara, F. Iacomi, J. M. Zaleski, J. B. Bai, Electron spin resonance spectroscopy investigations of carbon nanotubes-epoxy composites, $J$. Optoelectron. Adv. M., 8 (2006), pp. 820-824.

[9] V. Likodimos, S. Glenis, N. Guskos, C. L. Lin, Magnetic and electronic properties of multiwall carbon nanotubes, Phys. Rev. B, 68 (2003), pp. 045417.

[10] S. Garaj, L. Thien-Nga, R. Gaal, L. Forro, K. Takahashi, F. Kokai, M. Yudasaka, S. Iijima, Electronic properties of carbon nanohorns studied by ESR, Phys. Rev. B, 62 (2000), pp. 17115.

[11] M. Chipara, J. M. Zaleski, D. Hui, C. Du, N. Pan, Electron spin resonance on carbon nanotubespolymer composites, J. Polym. Sci. Polym. Phys. 43 (2005), pp. 3406-3412.

[12] D. Arcon, A. Zorko, P. Cevc, A. Mrzel, M. Remskar, R. Dominko, M. Gaberscek, D. Mihailovic, Electron spin resonance of dopedchalcogenide nanotubes, Phys. Rev. B, 67 (2003), pp. 125423.

[13] A. Ivanoska-Dacikj, G. Bogoeva-Gaceva, S. Valić, S. Wießner, G. Heinrich, Benefits of hybrid nanofiller networking between organically modified montmorillonite and carbon nanotubes in natural rubber: experiments and theoretical interpretations, Appl. Clay Sci., 136 (2017), pp. 192-198.

[14] M. Chipara, K. Lozano, R. Wilkins, E. V. Barrera, M. X. Pulikkathara, L. Penia-Para, M. Chipara, ESR investigations on polyethylene-single wall carbon nanotube composites, J. Mater. Sci., 43 (2008), pp. 1228-1233. DOI $10.1007 / \mathrm{s} 10853-007-2264-8$ 
[15] R. C. Barklie, Characterisation of defects in amorphous carbon by electron paramagnetic resonance. Diam. Relat. Mater., 12 (2003), pp. 1427-1434. DOI: 10.1016/S0925-9635(03)00004-9

[16] Y. F. Lan, J. J. Lin, Observation of carbon nanotube and clay micellelikemicrostructures with dual dispersion property. J. Phys. Chem. A, 113 (2009), pp. 8654-8659. DOI: $10.1021 /$ jp9026805

[17] A. Ivanoska-Dacikj, G. Bogoeva-Gaceva, A. Buzarovska, Clay improved dispersion of carbon nanotubes in different solvents, Contributions, Sec. Nat. Math. Biotech. Sci., MASA, 36 (2015), pp. 5-10.

[18] A. Ivanoska-Dacikj, G. Bogoeva-Gaceva, S. Rooj, G. Heinrich, S. Wießner, Fine tuning of the dynamic mechanical properties of natural rubber/carbon nanotube nanocomposites by organically modified montmorillonite: A first step in obtaining high- performance damping material suitable for seismic application, Appl. Clay Sci., 118 (2015), pp. 99-106.

DOI: 10.1016/j.clay.2015.09.009

[19] S. Rooj, A. Das, K. W. Stöckelhuber, S. Wießner, D. Fischer, U. Reuter, G. Heinrich, 'Expanded organoclay' assisted dispersion and simultaneous structural alterations of multiwall carbon nanotube (MWCNT) clusters in natural rubber, Compos. Sci. Technol., 107 (2015) 36-43.

DOI: 10.1016/j.compscitech.2014.11.018

[20] M. Klüppel, The role of disorder in filler reinforcement of elastomers on various length scales, Adv. Polym. Sci., 164 (2003), pp. 1-86.

[21] A. Das, K. W. Stöckelhuber, R. Jurk, M. Saphiannikova, J. Fritzsche, H. Lorenz, M. Klüppel, G.
Heinrich, Modified and unmodified multiwalledcarbon nanotubes in high performance solution-styrene-butadiene and butadiene rubber blends, Polymer 49 (2008), pp. 5276-5283. DOI: http://dx. doi.org/10.1016/j.polymer.2008.09.031

[22] W. D. Rice, R. T. Weber, A. D. Leonard, J. M. Tour, P. Nikolaev, S. Arepalli, V. Berka, A.-L. Tsai, J. Kono, Enhancement of the electron spin resonance of single-walled carbon nanotubes by oxygen removal, ACS Nano. 6 (2012), pp. 21652173. DOI: $10.1021 / \mathrm{nn} 204094 \mathrm{~s}$

[23] C. P. Poole, H. A. Farach, Lineshapes. In: Poole, C. P. and Farach, H. A. (eds.), Handbook of Electron Spin Resonance, Volume 2, Springer-Verlag, New York, 1999, pp. 47-67.

[24] K. A. Müller, Spin Resonance in NeutronIrradiated Graphite. Phys. Rev. 123 (1961), pp. 1550-1552.

DOI: http://dx.doi.org/10.1103/PhysRev.123.1550

[25] F. Beuneu, C. l'Huillier, Modification of multiwall carbon nanotubes by electron irradiation: An ESR study, Phys. Rev. B, 59 (1999), pp. 5945-5949. DOI: http://dx.doi.org/10.1103/PhysRevB.59.5945

[26] G. Heinrich and M. Klüppel, Recent advances in the theory of filler networking in elastomers. In: Lee, K.S. (Ed.), Filled Elastomers Drug Delivery Systems Series: Advances in Polymer Science. Springer, Berlin, 2002, pp. 1-44. DOI: $10.1007 / 3-540-45362-8 \_1$

[27] G. Kraus, Mechanical losses in carbon black filled rubbers. J. Appl. Polym. Sci. Symp., 39 (1984), pp. 75-92.

\title{
ЕЛЕКТРОН-СПИНСКА РЕЗОНАНЦИЈА НА ХИБРИДНИ НАНОКОМПОЗИТИ НА БАЗА НА ПРИРОДНА ГУМА
}

\section{Александра Иваноска-Дациќ ${ }^{1}$, Гордана Богоева-Гацева ${ }^{1,2}$, Среќко Валиќ́ $^{3,4}$}

\author{
${ }^{1}$ Истражувачки центар за животна средина и материјали, \\ Македонска академија на науките и уметностите, Скопје, Република Македонија \\ ${ }^{2}$ Технолошко-металуршки факултет, Универзитет „Св. Кирил и Методиј“, \\ Скопје, Република Македонија \\ ${ }^{3}$ Оддел за хемија и биохемија, Медицинско училиштеи центар за нано-науки и технологии, \\ Универзитет во Ријека, Ријека, Хрватска \\ ${ }^{4}$ Институт „Руѓер Бошковиќ“, Загреб, Хрватска
}

\begin{abstract}
Методот електрон-спинска резонанција (ЕСР) е применет како нова алатка за анализа на синергијата меѓу две нанополнила различни по природа, форма и ригидност, диспергирани во матрица од природна гума. Испитувани се примероци од природна гума наполнети со хибридно полнило од повеќеsидни јаглеродни наноцевки (2 дела на 100 дела еластомер) и експандиран органомодифициран монморилонит (ЕОМт, 4 до 20 дела на 100 дела еластомер). Утврдена е зависност на двојниот интеграл на резонантниот спектар од количината на ЕОМт во природната гума. Неговото намалување со зголемување на концентрацијата на ЕОМт ја потврдува синергијата меѓу двете употребени нанополнила. Паралелно со ЕСРсенаправени и динамичкомеханички мерења при променлива температура, при што е искористен моделот на кластеркластер агрегација за процена на привидната енергија на вмрежување. Добиените резултати сугерираат дека
\end{abstract}


ЕОМт употребен во хибридното полнило над одредена критична концентрација придонесува за зајакнати мрежни интеракции меѓу полнилата.

Клучни зборови: електрон-спинска резонанција, јаглеродни наноцевки, органски-монтморилонит, еластомерни нанокомпозити 